\title{
Cyclic Fatigue Resistance of Biorace Nickel-titanium File with Variable Taper after Immersion in Sodium Hypochloride
}

\section{Sodyum Hipokloritin Farklı Taperlardaki Biorace Nikel Titanyum Eğesinin Döngüsel Yorgunluk Direncine Etkisinin Değerlendirilmesi}

\author{
(D) Burçin ARICAN, iD Ayfer ATAV ATEŞ
}

İstanbul Okan University Faculty of Dentistry, Department of Endodontics, İstanbul, Turkey

\begin{abstract}
Objective: This study aimed to evaluate the effect of sodium hypochlorite on the cyclic fatigue resistance of BioRace (BR) files according to taper.

Methods: BR 25.04 and 25.06 files were divided into the following groups: group 1, $20 \mathrm{BR} 25.04$ with no immersion in $\mathrm{NaOCl}$; group 2, 20 BR 25.04 with immersion in $5.25 \% \mathrm{NaOCl}$ at $37{ }^{\circ} \mathrm{C} \pm 1{ }^{\circ} \mathrm{C}$ for 5 min; group 3, $20 \mathrm{BR} 25.06$ with no immersion; and group 4, 20 BR 25.06 with immersion in $5.25 \% \mathrm{NaOCl}$ at $37^{\circ} \mathrm{C} \pm 1{ }^{\circ} \mathrm{C}$ for 5 $\mathrm{min}$. The instruments were applied to a stainless-steel artificial root canal of $60^{\circ}$ curvature and $5-\mathrm{mm}$ radius. The time to failure (TTF) in seconds and number of cycles to failure (NCF) were recorded.

Results: The cyclic fatigue resistance of BR 25.04 was significantly higher than that of BR 25.06. The TTF and NCF values were significantly higher in group 1 than in groups 2 and 3 and in group 2 than in group 4 . However, neither value differed significantly between groups 3 and 4 ( $>>0.05)$.
\end{abstract}

Conclusion: Taper and sodium hypochlorite affected the cyclic fatigue resistance of $\mathrm{BR}$.

Keywords: BioRace, cyclic fatigue resistance, sodium hypochlorite, taper

\section{ÖZ}

Amaç: Bu çalışmanın amacı sodyum hipokloridin farklı taperlara sahip olan BioRace (BR) döner alet sisteminin döngüsel yorgunluğuna etkisini değerlendirmektir.

Yöntemler: BR 25,04 ve BR 25,06 enstrümanlarının döngüsel yorgunlukları, farklı koşullarda test edildi. Grup 1, BR 25,04 nolu eğe hiç bir solüsyonda bekletilmeden; grup 2: BR 25,04 \%5,25 $\mathrm{NaOCl}$ solüsyonunda $37{ }^{\circ} \mathrm{C} \pm 1{ }^{\circ} \mathrm{C}$ 'de 5 dakika bekletilerek; grup 3: BR 25,06 hiç bir solüsyonda bekletilmeden; grup 4: BR 25,06 $\% 5,25 \mathrm{NaOCl}$ solüsyonunda $37^{\circ} \mathrm{C} \pm 1^{\circ} \mathrm{C}$ 'de 5 dakika bekletildikten sonra $60^{\circ}$ kurvatür açılı and $5 \mathrm{~mm}$ kurvatür yarıçaplı paslanmaz çelik bloktan üretilmiş eğimli olukta test edildi. Her bir eğenin kırılana kadarki döngü sayısı (NCF) ve kırılana kadarki süresi (TTF) saniye cinsinden kaydedildi. Elde edilen veriler istatistiksel analizler ile değerlendirildi.

Bulgular: BR 25,04 eğesinin döngüsel yorgunluk direnci, BR 25,06 'dan istatistiksel olarak daha yüksektir. TTF ve NCF değerleri grup $1>\operatorname{grup} 2$, grup $1>$ grup 3 , grup $2>$ grup 4 şeklinde bulundu. Buna karşılık, grup 3 ve grup 4 arasında istatistiksel olarak anlamlı bir fark yoktu.

Sonuç: Bu çalışmanın sınırları doğrultusunda BR ensturmanlarının taperı ve sodyum hipokloritte bekletilmesi aletin döngüsel yorgunluğuna etki etmektedir.

Anahtar Sözcükler: BioRace, döngüsel yorgunluk direnci, sodyum hipoklorit, taper
Address for Correspondence: Burçin ARICAN ÖZTÜRK, İstanbul Okan University Faculty of Dentistry, Department of Endodontics, istanbul, Turkey

E-mail: burcinaricanozturk@gmail.com ORCID ID: orcid.org/0000-0001-5757-0571
Received: 26.11 .2019

Accepted: 07.01.2020

Cite this article as: Arıcan Öztürk B, Atav Ateş A. Cyclic Fatigue Resistance of Biorace Nickel-titanium File with Variable Taper after Immersion in Sodium Hypochloride. Bezmialem Science 2021;9(1):25-8. 


\section{Introduction}

File failure during root canal instrumentation is challenging (1). Fracture of nickel-titanium (Ni-Ti) files can be caused by torsional stress or cyclic fatigue. Cyclic fatigue can occur when a file is exposed to repeated compression and tension $(2,3)$. To reduce the frequency of fracture, new instruments manufactured from advanced alloys have been developed.

BioRace instruments (BR; FKG, La Chaux-de-Fonds, Switzerland) are manufactured from conventional austenite $\mathrm{Ni}-\mathrm{Ti}$ and include six rotary instruments with electropolished surfaces, safety tips, triangular cross-sections with alternating cutting edges $(4,5)$, and tapers of 0.02 to 0.08 (6).

Several factors influence the cyclic fatigue resistance of endodontic instruments, such as the manufacturing process, rotation type, operational speed, metal surface treatment, and immersion in disinfection solution $(2-4,7)$. $\mathrm{NaOCl}$ solution is used for irrigation during endodontic procedures, and $\mathrm{Ni}-\mathrm{Ti}$ instruments come into contact with this solution during root canal instrumentation and disinfection $(8,9)$, which corrodes the instruments and does affect their cyclic fatigue resistance $(2,10$ 12). However, contradictory results have been reported, which are likely due to differences in conditions (9-12).

To our knowledge, no study has investigated the effect of taper and $\mathrm{NaOCl}$ on the cyclic fatigue resistance of a file. Thus, this study aimed to evaluate the effect of $\mathrm{NaOCl}$ and taper on the cyclic fatigue resistance of $\mathrm{BR} \mathrm{Ni-Ti}$ instruments. The null hypotheses were as follows:

1. The cyclic fatigue resistance of the file is not affected by its taper.

2. The cyclic fatigue resistance of the file is not affected by immersion in $\mathrm{NaOCl}$ solution.

\section{Method}

In this study, we tested the cyclic fatigue resistance of $40 \mathrm{BR} 3$ (25.04) and $40 \mathrm{BR} 4(25.06) \mathrm{Ni}$-Ti files in an artificial curved canal after immersion in $\mathrm{NaOCl}$. The instruments were inspected under a surgical microscope (M320, Leica Microsystems, Wetzlar, Germany) at 20x magnification for defects and deformities. None of the instruments was discarded.

The files were randomly divided into the following groups $(\mathrm{n}=20$ each): group 1, BR 3 with no immersion; group 2, BR 3 with immersion in $5.25 \% \mathrm{NaOCl}$ at $37{ }^{\circ} \mathrm{C} \pm 1{ }^{\circ} \mathrm{C}$ for 5 min; group 3 , BR 4 with no immersion; and group 4, BR 4 with immersion in $5.25 \% \mathrm{NaOCl}$ at $37{ }^{\circ} \mathrm{C} \pm 1{ }^{\circ} \mathrm{C}$ for 5 min. The working part of the instrument was statically immersed in $\mathrm{NaOCl}$ and rinsed in $10 \mathrm{~mL}$ of distilled water. Then, the $16-\mathrm{mm}$ working part of the instrument (curvature $60^{\circ}$, radius $5 \mathrm{~mm}$ ) was applied to the stainless-steel artificial root canal (width $1.5 \mathrm{~mm}$, depth $3.0 \mathrm{~mm}$ ). The center of the curvature was $5 \mathrm{~mm}$ from the tip of the instrument, and the curved segment of the canal was $5 \mathrm{~mm}$ long. To reduce friction, synthetic oil was applied to the canal. The instruments were rotated freely inside the canal using an X Smart endodontic motor at $600 \mathrm{rpm}$ and $1 \mathrm{~N} / \mathrm{cm}$ until fracture occurred (Figure 1). To mimic physiological conditions, continuous irrigation with distilled water at $37^{\circ} \mathrm{C}$ was performed.

\section{Statistical Analysis}

The time to failure (TTF; in seconds) was recorded both visually and audibly. The number of cycles to failure (NCF) was calculated by multiplying the time(s) to failure by the number of rotations or cycles per second, regardless of the direction of rotation (13). Data were subjected to the Shapiro-Wilk test to verify the assumption of normality. One-way analysis of variance and Tukey's multiple-comparison test were performed using $\mathrm{NCSS}^{\text {TM }}$ 2007 software (NCSS, Kaysville, UT) with a significance level of 0.05 . TTF and NCF values were subjected to Weibull reliability analysis to calculate the probability of survival.

\section{Results}

The mean NCF and TTF values are shown in Tables 1 and 2 . The mean TTF of the BR 25.04 groups (groups 1 and 2) was greater than that of the BR 25.06 groups (groups 3 and 4). The resistance to cyclic fatigue of the $B R$ instrument with a 0.06 taper was not significantly affected by immersion in $\mathrm{NaOCl}$. However, static immersion in $\mathrm{NaOCl}$ for 5 min significantly reduced the cyclic fatigue resistance of the instrument with a 0.04 taper. The TTF and NCF values were significantly higher in group 1 than in groups 2 and 3 and in group 2 than in group 4 . However, neither value differed significantly between groups 3 and 4 ( $>>0.05)$.

Weibull reliability plots with probability of survival values are shown in Figure 1, and the Weibull modulus, $\mathrm{R}^{2}$, and number of cycles to $99 \%$ survival are presented in Table 2 . The predicted TTFs for groups 1, 2, 3, and 4 were 43.24, 34.36, 25.38, and 26.62 s, respectively. The predicted number of cycles to $99 \%$ survival in groups $1,2,3$, and 4 was 206.83, 186.68, 127.81, and 110.28 , respectively.

Figure: Survival Graph

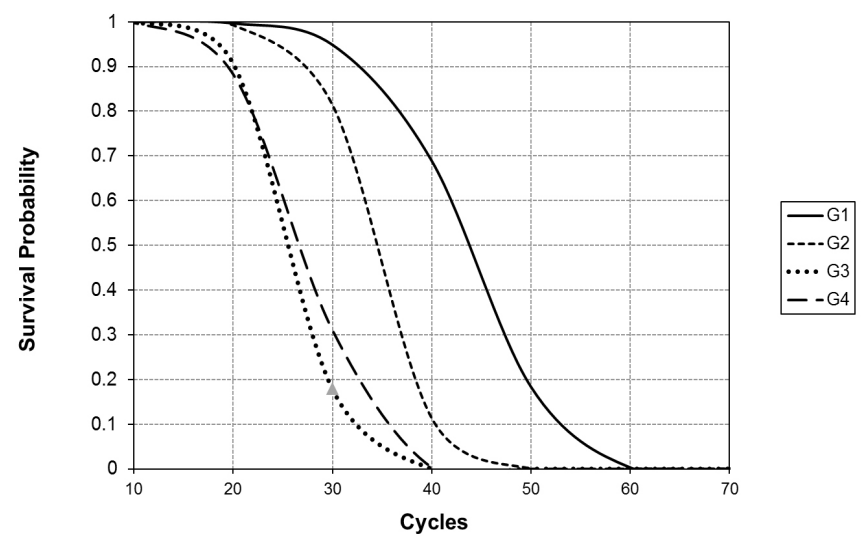

Figure 1. Probability of Survival Values of Groups (NCF, number of cycles to failure)

NCF: Number of cycles to failure 


\section{Discussion}

We evaluated the effect of $\mathrm{NaOCl}$ on the cyclic fatigue resistance of a BR Ni-Ti instrument with different tapers. The null hypotheses that taper (BR) and immersion in $\mathrm{NaOCl}$ would not affect the cyclic fatigue resistance were rejected.

The cyclic fatigue resistance of a file decreases with increasing metal volume (14). In this study, files of one tip size but different tapers were tested to exclude the influence of other variables such as alloy type, cross section, and kinematics $(7,15)$. Compared with BR 4 (0.06 taper), BR 3 (0.04 taper) had better cyclic fatigue resistance and NCF value regardless of immersion in $\mathrm{NaOCl}$. This is in agreement with prior reports $(16,17)$.

There is no universally accepted method for testing the cyclic fatigue resistance of endodontic instruments. Although the use of human teeth would be representative, it is impossible to standardize the tooth morphology (18). For this reason, artificial root canals are used to test cyclic fatigue resistance. Given the difficulty of shaping curved canals in the endodontic clinic, previous in vitro studies used $45^{\circ}, 60^{\circ}, 75^{\circ}$, and $90^{\circ}$ curved canals of 5 -mm radius $(2,13,18)$. In this study, based on Pruett's method, a stainless-steel artificial root canal of $60^{\circ}$ curvature and 5-mm radius was selected (19).

Endodontic instruments come into contact with $\mathrm{NaOCl}$ during root canal instrumentation and disinfection (12). Past studies of the effect of corrosion by $\mathrm{NaOCl}$ on the cyclic fatigue resistance of Ni-Ti instruments have yielded contradictory results $(2,10)$. This could be caused by differences in the immersion time (1 min to $48 \mathrm{~h}$ ), immersion type (static or dynamic), test protocol, instrument, heating $\left(21^{\circ} \mathrm{C}-60^{\circ} \mathrm{C}\right)$, and concentration (9-12). Berutti et al. (10) evaluated the effect of hot $\mathrm{NaOCl}$ on a Protaper instrument using a 5-min contact time, and corrosion reduced its cyclic fatigue resistance. Saber et al. (18) investigated the effect of instrument material, taper, and degree of root canal curvature on the cyclic fatigue of the ProFile GT and Profile GT Series X. Instrument taper affected the cyclic fatigue resistance of both instruments. Topçuoğlu et al. (20) reported that immersion in $5 \% \mathrm{NaOCl}$ for 5 min significantly decreased the cyclic fatigue resistance of several retreatment files with large metal volume. Elnaghy and Elsaka reported that the cyclic fatigue resistance of WaveOne Gold and Reciproc was considerably decreased by immersion in saline and $\mathrm{NaOCl}$ at $37^{\circ} \mathrm{C}(2)$. However, Pedulla et al. (12) found that static or dynamic immersion in $\mathrm{NaOCl}$ for 1 or $5 \mathrm{~min}$ did not reduce the cyclic fatigue resistance of $\mathrm{Ni}-\mathrm{Ti}$ instruments. Herein, we focused on the effects of taper and immersion time using a protocol based on that of Pedulla et al. (12). The 16-mm working part of the instrument was immersed in $\mathrm{NaOCl}$ at $37^{\circ} \mathrm{C} \pm 1{ }^{\circ} \mathrm{C}$ to simulate in vivo conditions. In this way, galvanic corrosion phenomena caused by differences in the shape of the shaft and the working part of the instrument were eliminated (10). We used 5-min contact with $\mathrm{NaOCl}$ to simulate clinical practice (12).

Weibull analysis enables evaluation of the probability of instrument survival and prediction of the time and number of cycles to $99 \%$ survival. Higher Weibull modulus values indicate better reliability (21). BR 4 with immersion in $\mathrm{NaOCl}$ (group 4) had the lowest Weibull modulus and the fewest cycles (11.03) and shortest time (110.28 s) to $99 \%$ survival. BR 3 (no immersion) had the largest number of cycles to $99 \%$ survival (20.68) (Table 2).

Table 1. Comparison of time to fracture of groups with mean \pm standard deviation (statistical level at $p \leq 0.05$ )

\begin{tabular}{|l|l|l|l|}
\hline & No immersion & Immersion in NaOCl & \multicolumn{1}{c|}{ P value } \\
\hline & Mean \pm SD & Mean \pm SD & 0.001 \\
\hline 25.04 BioRace (BR3) & $\begin{array}{l}\text { Group 1: } \\
43.24(7.37)\end{array}$ & $\begin{array}{l}\text { Group 2: } \\
34.35(4.73)\end{array}$ & Group 4: \\
\hline 25.06 BioRace (BR4) & Group 3: & $26.62(5.28)$ & 0.668 \\
\hline P value & $25.88(4.02)$ & 0.000 & \\
\hline SD: Standard deviation & 0.000 & &
\end{tabular}

Table 2. Sample size, NCF, Time to Fracture, Weibull Calculations Weibull calculations included Weibull modulus, coefficient of determination $\left(\mathrm{R}^{2}\right)$, and predicted cycles for \%99 survival and time

\begin{tabular}{|c|c|c|c|c|c|c|}
\hline G1 & 43.24 & 432.40 & 6.24 & 0.92 & 20.68 & 206.83 \\
\hline G2 & 34.36 & 343.60 & 7.54 & 0.90 & 18.67 & 186.68 \\
\hline G3 & 25.88 & 258.80 & 6.52 & 0.84 & 12.78 & 127.81 \\
\hline
\end{tabular}

SD: Standard deviation, NCF: Number of cycles to failure 


\section{Conclusion}

Taper and $\mathrm{NaOCl}$ affected the cyclic fatigue resistance of $\mathrm{BR}$ files. As the taper of the BR file increased, the cyclic fatigue resistance decreased. In contrast, immersion in $\mathrm{NaOCl}$ decreased the cyclic fatigue resistance of BR instruments with a 0.04 taper but had no effect on those with a 0.06 taper.

\section{Ethics}

Ethics Committee Approval: All procedures performed in studies involving human participants were in accordance with the ethical standards of the institutional and/or national research committee and with the 1964 Helsinki declaration and its later amendments or comparable ethical standards.

Informed Consent: For this type of study, formal consent is not required.

Peer-review: Externally peer reviewed.

\section{Authorship Contributions}

Surgical and Medical Practices: B.A.Ö., Concept: B.A.Ö., A.A.A., Design: B.A.Ö., A.A.A., Data Collection or Processing: A.A.A., Analysis or Interpretation: B.A.Ö., A.A.A., Literature Search: B.A.Ö., A.A.A., Writing: B.A.Ö.

Conflict of Interest: No conflict of interest was declared by the authors.

Financial Disclosure: The authors declared that this study received no financial support.

\section{References}

1. Cheung GSP. Instrument fracture: mechanisms, removal of fragments and clinical outcomes. Endod Topics 2007;16:1-26.

2. Elnaghy AM, Elsaka SE. Effect of sodium hypochlorite and saline on cyclic fatigue resistance of WaveOne Gold and Reciproc reciprocating instruments. Int Endod J 2017;50:991-8.

3. Ertuğrul IF, Orhan EO. Cyclic fatigue and energy dispersive X-ray spectroscopy examination of the novel ROTATE instrument. Microsc Res Tech 2019;1-7.

4. Lopes HP, Elias CN, Vieira VT, Moreira EJ, Marques RV, de Oliveira JC, et al. Effects of electropolishing surface treatment on the cyclic fatigue resistance of BioRace nickel-titanium rotary instruments. J Endod 2010;36:1653-7.

5. Freire LG, Gavini G, Branco-Barletta F, Sanches-Cunha R, dos Santos M. Microscopic computerized tomographic evaluation of root canal transportation prepared with twisted or ground nickel-titanium rotary instruments. Oral Surg Oral Med Oral Pathol Oral Radiol Endod 2011:112;143-8.

6. FKG. BioRace brochure. Available at: https://www.fkg.ch/sites/ default/files/fkg_br_brochure_an_lowr.pdf. Accessed at 20.11.2019.
7. Gambarini G, Grande NM, Plotino G, Somma F, Garala M, De Luca $\mathrm{M}$, et al. Fatigue resistance of engine-driven rotary nickel- titanium instruments produced by new manufacturing methods. J Endod 2008:34;1003-5.

8. O'Hoy PY, Messer HH, Palamara JE. The effect of cleaning procedures on fracture properties and corrosion of NiTi files. Int Endod J 2003;36:724-32.

9. Darabara M, Bourithis L, Zinelis S, Papadimitriou GD. Susceptibility to localized corrosion of stainless steel and $\mathrm{NiTi}$ endodontic instruments in irrigating solutions. Int Endod J 2004;37:705-10.

10. Berutti E, Angelini E, Rigolone M, Migliaretti G, Pasqualini D. Influence of sodium hypochlorite on fracture properties and corrosion of ProTaper Rotary instruments. Int Endod J 2006;39:693-9.

11. Haikel Y, Serfaty R, Wilson P, Speisser JM, Allemann C. Mechanical properties of nickeltitanium endodontic instruments and the effect of sodium hypochlorite treat- ment. J Endod 1998;24:731-5.

12. Pedulla E, Grande N, Plotino G, Pappalardo A, Rapisarda E. Cyclic Fatigue Resistance of Three Different Nickel-Titanium Instruments after Immersion in Sodium Hypochlorite. J Endod 2011;37:113942.

13. Kim HC, Kwak SW, Shun-Pan Cheung G, Ko DH, Chung S, Lee W. Cyclic Fatigue and Torsional Resistance of Two New NickelTitanium Instruments Used in Reciprocation Motion: Reciproc Versus WaveOne. J Endod 2012;38:541-4.

14. Sattapan B, Nervo GJ, Palamara JE, Messer HH. Defects in rotary nickel-titanium files after clinical use. J Endod 2000;26:161-5.

15. Karataş E, Arslan H, Büker M, Seçkin F, Çapar ID. Effect of movement kinematics on the cyclic fatigue resistance of nickeltitanium instruments. Int Endod J 2016;49:361-4.

16. Schrader C, Peters OA. Analysis of torque and force with differently tapered rotary endodontic instruments in vitro. J Endod 2005;31:1203.

17. Barbosa F, gomes J, De araújo $\mathrm{M}$. Influence of previous angular deformation on flexural fatigue resistance of K3 nickel- titanium rotary instruments. J Endod 2007;33:1477-80.

18. Saber SMS, Seeda MMA, Hassanien E. The effect of instrument material, taper and degree of root canal curvature on cyclic fatigue of rotary nickel-titanium instruments. ENDO (Lond Engl) 2013;7:5964

19. Pruett JP, Clement DJ, Carnes DL. Cyclic fatigue testing of nickel titanium instruments. J Endod 1997;23:77-85.

20. Topçuoğlu HS, Pala K, Aktı A, Düzgün S, Topçuoğlu G. Cyclic fatigue resistance of D-RaCe, ProTaper, and Mtwo nickel-titanium retreatment instruments after immersion in sodium hypochlorite. Clin Oral Invest 2016;20:1175-9.

21. Nguyen HH, Fong H, Paranjpe A, Flake NM, Johnson JD, Peters OA. Evaluation of the resistance to cyclic fatigue between ProTaper Next, ProTaper Universal, and Vortex Blue rotary instruments. J Endod 2014;40:1190-3. 